\title{
Indonesian Transnational Community in the Middle East: The Case of Gontor Alumni Association
}

\author{
Dhita Ayomi Purwaningtyas ${ }^{1}$, Muhamad Syauqillah ${ }^{2}$ \\ \{dhitaayomi@gmail.com¹, muhamadsyauqillah@ui.ac.id² \\ ${ }^{1,2}$ School of Strategic and Global Studies, Universitas Indonesia, Jakarta, Indonesia
}

\begin{abstract}
Santri is a term for pesantren students. During the rise of the Islamic movement, santri are still the mainstream of the ideal Muslim community's identity. Pesantren Gontor was considered successful in educating its students. Evidenced by the alumni as national figures, intellectuals, and religious leaders scattered in Indonesia and throughout the world. There are monitoring and guidance to maintain some of the values of Gontor after Gontor Alumni graduated. Pondok Modern Family Association (IKPM) is the organization responsible for this maintenance. This research will discuss how Gontor through IKPM maintains the value of santri in the Middle East that is considered vulnerable to Islamic issues. This paper uses the theory of transnationalism and the qualitative method through interviews and literature. The results of this study are the mission of IKPM to maintain the values of santri through social activities, education, preaching, publications, and economic endeavors. In the Middle East case, the role of IKPM is very prominent in the field of education. The collaboration between Gontor and several universities in the Middle East ease alumni to continue their studies.
\end{abstract}

Keywords: Gontor, Middle East, Pesantren, Santri, Transnationalism

\section{Introduction}

Indonesia, as a democratic state with a majority Muslim population, has a varied style of Islam. Cliffords Geertz in "The Religion of Java" divides Javanese Muslims into three groups, namely santri, priyayi, and abangan. Santri is a term for orthodox Muslims when compared to the abangan who are still adorned by the occult [1]. In the current issue, the santri, as claimed by Geertz, have their derivatives from the orthodoxy form. Although orthodox Muslims are not only from the pesantren santri, the existence of the santri itself still has an essential position in Indonesia's mainstream Islam.

Since the 18th century until now, Islamic institutions in Indonesia, pesantren, are still the same and developing. Its existence, which is not a total adoption of Middle Eastern Islam, gives an Islamic style in Indonesia. Hence the resulting santri more plunge into mainstream Islam, which is moderate and progressive. The rise of conservatism and radicalism in the colors of Indonesian Islam comes from the influence of the Middle East and Arabization in Indonesia [2]. Pesantren became the initial stronghold of this influence.

Pesantren initially focused on religious knowledge. The establishment of pesantren in Indonesia started from the figure of a cleric who wanted to teach the Qur'an and several Islamic studies in a langgar or mosque. A large number of students attending the study, which later 
became an initiative to make the hostel as a residence for students who later called santri [3]. The needs of the community and the idea of renewal in the Islamic education system, provide a variant in the pesantren system. In addition to traditional forms with classical systems, several innovations are also present in the scope of pesantren. One of them is a new boarding school.

The Modern Islamic Boarding School Gontor, located in Ponorogo, was the first modern pesantren in Indonesia that was founded in 1926. Modern in that era was to combine secular education using Arabic and English as the language of instruction. Interestingly, the founder of the Gontor boarding school never studied in the Middle East as the founder of traditional pesantren in general. They have a traditional pesantren educational background and the Muhammadiyah's Muallimin system.

The alumni profile of Gontor is very diverse. Not all become teachers as Gontor's jargon is a teacher training college, but also in the realm of business, government, intellectuals, da'wah, and literature. Multicultural education taught at Gontor makes its alumni acceptable in all social communities both at home and abroad [4]. The message of social education summarized in the hostel, class, and organization. The regulation does not allow students from the same regional background to make them able to mingle with anyone.

Now Gontor alumni has spread throughout Indonesia and abroad. The existence of a transnational alumni community colors Indonesian diaspora activities. The profile of the santri in the organization also makes the santri identity brought not only to the pesantren or Indonesian Muslim circles. Pesantren's existence in creating milieu santri is needed in addition to stemming from Islamic radicalism, as well as a role model of society. Bung Hatta, the founding father of Indonesia, even commented that the pesantren formed a sense of religion, unity, and character with simplicity and practice. Whereas schools and madrasas only increase mere intellectualism $[5]$.

Many pesantren studies have been carried out. Geertz was the pioneer of the pesantren research. In its development, there was a conflict because of the progress of the researchers' findings afterward. The discussion on pesantren is more focused on the study of Islamic education and pesantren traditions, as conducted by Zamakhsyari Dhofier (2011) and Karel A. Steenbrink (1986). Martin van Bruinessen (1990) conducted a study of pesantren seen in the Indonesian Islamic movement. Pesantren is Indonesia's sustainable cultural heritage so that anthropological studies have conducted in pesantren research by Fauzi (2012).

Research on the sustainability of the pesantren tradition was carried out by Miftahcul Huda, Kamarul Azmi Jasmi, and friends entitled "Traditional Wisdom in Sustainability Learning: An Insightful View From Al-Zarnuji's Ta'lim al-Muta'allim". This research makes the traditional pesantren's mandatory book, Ta'lim al-Muta'allim, the object of study. Wisdom and morals in this book become one of the points in teaching.

Gontor as the object of study has been conducted by several researchers such as Zulkarnain (2015), Syam (2015), Phase (2017) and Niam (2018). Thesis written by Muhamad Nizhomun Niam entitled "Penanaman Pendidikan Life Skill dalam Meningkatkan Kemandirian Santri Baru di Pondok Modern Gontor Putra II Madusari Siman Ponorogo 2017/2018” and Aldo Redho Syam's research entitled "Manajemen Pendidikan Kedisiplinan Santri di Pondok Pesantren (Studi Kasus di Pondok Modern Darussalam Gontor Ponorogo)" discusses the character education pattern of the Gontor pesantren. While the journal written by Fisher Zulkarnain in the Islamic Education Journal entitled "The Thought of KH Imam Zarkasyi on Multicultural Education of Modern Islamic Boarding School, Gontor Ponorogo" examines Gontor in terms of the thinking born of its founder, Imam Zarkasyi. Muhammad Iqbal Phase's research entitled "Gontor as the Learning Contemporary Islamic Institution Transformation Toward the 
Modernity", published by the journal Hunafa: Journal of Studia Islamika, discusses the development of Gontor in education in the modern era.

This paper discusses students as objects of study because the sustainability of pesantren is not only in the existence of pesantren but also alumni who take part in the community, both in national and international scope. This research is new because no one has ever discussed the santri and pesantren networks.

This study is a qualitative study using interview techniques as primary data collection. The interviewees were Gontor alumni who joined the management of the Gontor IKPM in each region with a minimum of 3 years' length of stay. Speakers included GPM, Cairo, Medina, Sudan, Morocco, and Turkey. Interviews were conducted offline and online. Literature studies are used related to the theme of Islamic boarding schools and Gontor huts in the form of books and journals.

\section{Theoretical Framework}

\subsection{Transnationalism}

Transnationalism is an activity between people and groups in other countries based on the relation among the diaspora from the same country of origin, social movements, or religion. The many levels of migration of diaspora or expatriates are the impact of globalization, the ease of access to information, and transportation. Linkage conducted by non-state actors is more sustainable than the interactions between national governments [6]. The importance held in the idea of transnationalism is only the result of awareness of collective identity [7]. Transnationalism often used to refer to migrants' communities, social formation, organization, and groups, which sometimes have transnationally active networks [8].

\subsection{Social Identity}

Social identity is the study possessed by an individual that he is part of a social group with the same values and emotions [9]. This sense of ownership of a group derived from how it describes the characteristics of a group. The study of social identity is in the realm of social psychology that examines human social behavior.

Social categories refer to religion, race, nationality, class, occupation, gender, and alma mater. The social category exists because there is a comparison. Islam, as a religion, becomes a category in the social because it has a comparison with other religions. Even in Islam itself is divided into categories to a smaller degree, such as civil organizations. This comparison can be merged if the Islamic community in a country does not have another comparison. Then it is enough to become a social category.

Individual people are born in a social and merge with certain social entities as their existence. The higher the level of identification of a person in a group, the higher the attachment to that group. Appropriate organizational values and norms will attract someone to play an optimal role in the organization [10]. Individuals will identify the values and characters. 


\section{Pesantren Genealogy}

Institutionalized Islamic teachings have existed since the Abbasid period, the Nizhamiyah madrasa founded by Nizam al-Mulk (d.485 / 1092) in the regions of present-day Iraq and Iran [11]. Madrasa is the development of religious teaching during the time of sahabah in the form of halaqah or small groups. In halaqah, a group of students learns tafsir, hadith, or other religious sciences with one teacher. Whereas in the madrasa system, there are determined places, curriculum, and teacher each subject. Madrasas continued to grow until the golden age of Islamic scholar in Andalusia, which introduced the diploma system and later inspired the graduation procession. Islamic studies also includes the practice of Sufism, such as tekke in the Turkish and Balkan regions and rabat in Morocco. Madrasa al-Zahrah, initiated by Badiuzzaman Said Nursi since the time of Sultan Abdul Hamid, was an effort to study madrasa and secular science [12].

Similar institutions are also used in the study of other religions to produce religious leaders and clergy. Like Christian and Catholic seminary, which is equivalent to high school and college education with a bachelor's degree in religion or philosophy. While in Hinduism, there is pasraman from the word 'boarding' which means the place where the process of teaching and learning religion by emphasizing discipline and noble character. This market is also an absorption word in Indonesian, which means a place to live for students. In the archipelago, before the advent of Islam, there was already a Hindu religious education institution that had a student residence with the name Ashrama [13].

Some literature states that pasmaran is the forerunner to pesantren in Indonesia because the Javanese religion in the period before Islam was Hindu-Buddhist. However, this was rejected by Zamakhsyari Dhofier (2011), who stated that there had been Indonesian scholars who had lived a long time in Mecca during the wave of Hinduism in Southeast Asia [14]. The increase in Muslim pilgrimages in the 18th century became one of the transmissions of the Islamic style of Indonesia [15]. So that pesantren, which are now widespread in Indonesia, is the adoption of the learning systems they get in the Middle East, such as the halaqah in Mecca and student dormitories at Al-Azhar University. However, Islamic education in Indonesia does not necessarily detain Saudi Islam, which is laden with Wahabi-style purification or Egyptian reformists in the style of the Muslim Brotherhood. When the renewal of Islam in Egypt began to decline, the modernization of Islam in Indonesia began with the development of pesantren.

The use of the word madrasa was not common to refer to Islamic educational institutions in Indonesia. Madrasa refers more to Islamic public schools with a level of Ibtidaiyah (elementary), tsanawiyah (junior high school), and aliyah (senior high school) with learning $30 \%$ of religious science and $70 \%$ of secular science. Pesantren is an Islamic educational institution organized by the (private) community with a boarding system. Southeast Asian regions such as Malaysia, southern Thailand, and the southern Philippines use the word Pondok derived from the word funduq in Arabic, which means hostel and residence. The word Pondok is used in Indonesia as in pesantren. Some even use both words to become Islamic boarding schools. The pesantren etymologically derived from the word 'santri,' which means the place of santri [16]. Pondok, if translated into English, become Islamic boarding schools. However, Ronald Lukens Bull (2010), in his research, did not change the word pesantren into English because it would reduce the essence of the meaning of pesantren and not yet represent the sacredness of pesantren [17]. Some other words are used in various regions, such as Islamic boarding schools in Madura, rank meunasah in Aceh, and surau in Padang [18].

Historically, pesantren originated from the figure of an ulama (kyai) who became a reference in the science of religion. The religious teaching is the form of Qur'anic teaching as 
well as the tawhid and fiqh. The most suitable place for this teaching is the mosque or surau. Then those who want to gain knowledge come to the clerics. In its development, the number of students increased, so the dwelling hostel was built around the mosque or the kyai's house. Pesantren that have a similar history are Ploso Pesantren in Kediri, Pesantren Tebuireng in Jombang, and Darussalam Pesantren in Banyuwangi [19].

In general, typical pesantren in Indonesia are educational institutions with a classic system of sorogan and bandongan that use the yellow book as teaching material. The yellow book is used in pesantren is Arabic script. Both imported books are mostly from Lebanon and Egypt, as well as the writings of Indonesian scholars using Arabic or pegon (Javanese Arabic writing). There are differences among modern pesantren that use romanized Indonesian white books [20]. Even Lukens-Bull argues that pesantren is a place to seek blessings and rewards [21]. Traditional pesantren loaded with mysticism and Sufism with the figure of the cults of the kyai cult.

Permanent santri or round-trip santri study the yellow book with the kyai in the mosque. At least these five components, kyai, santri, boarding houses, mosques, and yellow books, must be fulfilled to be categorized as pesantren. In its development, the system and teaching materials changed according to the affiliations of the respective clerics. The Ministry of Religion of the Republic of Indonesia has accommodated pesantren matter through the Minister of Religion Regulation and Decree of the Director-General of Islamic Education. Even to recognize pesantren in the dynamics of education and nationalism in Indonesia, the government since 2018 has drafted a law on pesantren passed in 2019.

The first pesantren that can be tracked so far is Tegalsari Pesantren in Ponorogo. It was established in 1710 by Kiai Ageng Hasan Besari. According to Martin boarding school, Tegalsari was founded in [22]. The Tebuireng pesantren, which became the forerunner to the Nahdhatul Ulama, became the role model of a traditional pesantren [23].

\section{Brief of Pondok Modern Gontor}

Pesantren Tegalsari, as one of the pioneers of pesantren education, many students came from all regions in Java. After his death, the leader of the pesantren was replaced by Kiai Hasan Yahya, who was subsequently replaced by Kiai Bagus Hasan Besari II, who was replaced by Kiai Hasan Anom [24]. This change continued until the middle of the 19th century in the fourth generation of Kiai Besari. It was during this time that the Pesantren Tegalsari began to decline.

Kyai Khalifah, the fourth generation of Pesantren Tegalsari, sent one of the best sons-inlaw and students of his time to Gontor Village to establish a boarding school with a similar system. The santri was named Sulaiman Jamaluddin, who still had a lineage with Cirebon's tenancy. He was equipped with 40 students from Pesantren Tegalsari by Kiai Khalifah [25]. This Pesantren then named Pondok Gontor, which will henceforth be called The Old Pondok Gontor.

Gontor is the name of the local village, which stands for Kanggon Kotor, which means Dirty Place. Dirty means a form of activities of local villagers illustrated in Javanese philosophy as 5 cases of human moral destruction that is $5 \mathrm{M}$ or molimo. Molimo consists of main (gambling), madon (prostitution), maling (stealing, bribery, corruption or taking that is not right), madat (addictive substance addiction), and minum (drinking liquor). The establishment of the pesantren in Old Gontor was an attempt to spread Islamic education and traditions in that place. The hope is to be able to change the social life of the people of Gontor for the better [26]. 
Kiai Sulaiman has a child named Archam Anom Besari. During Kiai Archam's upbringing, the Old Gontor's cabin reached its golden age. He got help from the surrounding community. Cooperation is carried out by the cottage and residents, even on the side of protection and lodging. The explosion of the number of students caused some santri did not get a place in the dormitory. They can live in the housing of residents.

Pesantren then continued by Kiai Archom's son, Santoso Anom Besari. The old Gontor experienced a drastic decline after Santoso Anom Besari's death at a young age. The village of Gontor is again untouched by Islamic teachings until it is known as a den of thieves. None of his brothers were able to continue the cabin. He left his wife and seven children. Nyai Santoso is determined to revive Pondok Gontor again by sending his children to study religious knowledge in various regions in Indonesia. Some of his children continue their studies to Solo, Yogyakarta, and Padang. In 1926, the sixth child named Ahmad Sahal pioneered Pondok Gontor Baru. He was assisted by his eldest brother, Rahmat Soekarto, who was then serving as headman [27].

The teaching system initially took the form of Tarbiyatul Athfal as primary Islamic education. Because of its rapid development, in 1932, Sullamul Muta'allimin was founded, which later changed its name to Taman Perguruan Islam. The presence of his younger siblings Imam Zarkasyi and Zainuddin Fananie in 1935 after completing his education in Padang added to the idea of implementing pesantren. So in 1936, on the 10th anniversary of the Pondok, TPI was renamed Pondok Gontor Modern Darussalam. The three founders were then called Trimurti Founders of the Pondok. Nevertheless, there is also the term Empat Serangkai, Trimurti, and Rahmat Soekarto as defender of Pondok [28].

Gontor's modernization as a starting point for Pondok Gontor Modern is not a reformiststyle modernization that wants to restore the teachings to the Qur'an and Sunnah or is modern in terms of facilities. The modernization is a change in the traditional pesantren education system as a result of adaptation from Pesantren Tegalsari. Three things that are striking about this system change are the use of Arabic and English, the Muslim system, teaching materials, and character education.

Pondok Modern Gontor uses Arabic and English as the language of daily instruction and learning. This idea was broken down even before Pondok Gontor used the KMI system by Ahmad Sahal. In 1926 before the founding of Pondok Gontor Baru, he attended the Muslim Congress in Surabaya as a regional representative of Madiun. One of the themes discussed in the congress was the termination of the Indonesian delegation to be sent to the Islamic Conference in Mecca. The minimum requirement for delegates is to master the two international languages well. Because none of them met the criteria, finally, H.O.S Cokroaminoto and Mas Mansyur were chosen.

Imam Zarkasyi coined Kulliyatul Muallimin al-Islamiyah (KMI) as an education system in 1935. He was inspired by his experience of studying at the Normal Islamic School led by Mahmud Yunus in Padang Panjang and teaching at Kweekschool Muhammadiyah in Padang Sidempuan, North Sumatra. In the early days, the curriculum used was the adoption of Islamic Norms. However, after considering that the students he taught could not use the language actively, a new curriculum was changed. In Arabic and Nahwu, for instance, the textbook used was not the Alfiyah Book by Imam Mali, but Durusullughoh, as basic Arabic, the works of Imam Zarkasyi and Imam Syubbani, and Nahwu Wadhih 5 volumes. The yellow book, as the primary teaching material, sorogan, and bandongan as a teaching system in traditional pesantren, is not used. In the KMI system, the material taught includes Islamic studies and general material even though the amount of teaching time is not as much as public schools in general. 
Pesantren not only lies in understanding religion, foreign languages, buildings, and character. For Trimurti, the most crucial thing from pesantren is the life and education soul [29]. Trimurti also initiated the urgency of printing students to be the nation's successors with the formation of soul and personal excellence. This system is what modern education calls character education. Before the discourse of character education in the Indonesian education system in KTSP (Education Unit Level Curriculum) or the 2013 curriculum, Pondok Modern Gontor has been implementing it since the early 20 th century.

Although educational institutions generally inspire the madrasa and pesantren systems in the Middle East, Pondok Modern Gontor makes four institutions in the world as the synthesis of Pondok. First, Al-Azhar University because of its immortality and representation. This university has been established since 975, and now it is 1044 years old. This institution can also provide scholarships for thousands of students from all over the world. Second, Aligarh University in India, which is a pioneer of Islamic revival. This institution teaches religion and secular science as a step to improve the teaching and education system. Third, Syanggit, located in Mauritania, is a reflection of the generosity and sincerity of the caregivers. This educational institution covers all the needs of students. Fourth, Santiniketan in West Bengal, India. This place is an education city that has Visva-Bharati University. Previously, the Tagore family, the founder of the institute, built an ashram, which later became Santiniketan, which means a peaceful place to live. Ki Hadjar Dewantara also adapted the Santiniketan concept in the establishment of Taman Siswa College.

The position of Imam Zarkasyi in the Ministry of Religion has a significant role in religious education in Indonesia. Although the pesantren at the time was not yet recognized as an education unit, it fought for the existence of a madrasa as it is known today [30]. Madrasas are religious schools that also teach general subjects. Government Regulation No. 8 of 1950 and Government Regulation No.11 of 1949 became the beginning of the history of the madrasa.

\section{Value of Pesantren}

The Ministry of Religion Affairs states that pesantren students both traditional and modern must-have several competencies, including Nationalism, the spirit of science, sincerity, simplicity, ukhuwah Islamiyah, self-sufficient, freedom and moderate. The Five Spirit of Pesantren Gontor, which proclaimed since 1926, entered into these competencies, namely sincerity, simplicity, self-reliance, ukhuwah Islamiyah, and freedom. Besides that, Pesantren Gontor has a Mottoes of Pondok, which is often explained by kyai and ustadz that must be owned sequentially. A student must have good manners and good manners, then have a healthy body in order to be able to perform worship and activities to the maximum. Santri also must have extensive knowledge of who knows why he must study. If there are etiquette, body, and knowledge already possessed, students can think freely because they already have a strong foundation so that they are not free of values as a symbol of the maturity of education in pesantren.

The pesantren ideology generally adheres to the theology of Ash'ari and Maturidi. While Sufism uses the reference Ghazali and Shafi'i in fiqh, because it departs from traditional pesantren, the style of thought becomes the pattern of NU that has become Indonesia's mainstream Islam. Gontor Islamic Boarding School, according to Martin van Bruinessen (2013), tends to have the same ideology as the Indonesian Islamic Da'wah Council (DDII) after cooperation with Rabithatul 'Alam al-Islamy sponsored by Saudi Arabia [31]. However, this is 
refuted by the emergence of liberal Islamic alumni, Nurcholis Madjid. According to him, the Islamic characteristics of Gontor brought by Imam Zarkasyi were the characteristics of Islam in Padang and Java [32]. Padang's Islamic culture is dynamic and full of movement, while Javanese Islam's characters are perseverance and depth of studying Islam. They eventually became the object of a static study. The combination of both is produced in the form of behavior and soul.

Pesantren Gontor has a principle of standing above, and for all groups, the curriculum and lessons provided are the general foundation of students to see all kinds of differences. For basiclevel, students' material regarding Asy'ari's theology of the Khalaf. Then at the secondary level, students are taught tawhid salaf Ibn Taymiyah because they are considered capable of sorting out and conducting further discussions on the ideology. As for the basic level of fiqh, Imam Zarkasyi's book is taught with Shafi'i fiqh references. Then in the advanced level of Jurisprudence using ahkam al-hadiths. Only at the middle to upper levels did the students use Averosian's yellow book entitled Bidayah al-Mujtahid, which explained the differences in all schools. Comparative religion is taught as an introduction to religious plurality.

In terms of religious practices, the santri is free to perform rituals as he believes, either in the NU or Muhammadiyah ways. Nevertheless, if the prayer in the congregation, they have to follow what the imam does. This system was done to provide a basic understanding of students to accept various views but still have an attitude. In Karel A. Steenbrink's notes, Imam Zarkasyi agreed with Muhammadiyah's ideas in the field of aqeedah but disagreed with the overly dogmatic and violent preaching strategy by taking the example of West Sumatra during his early education [33].

Khutbatul 'Arsy Introductory Week (PKA) was held at the beginning of the school year as a period of orientation for new students and a review of old students [34]. The orientation is in the form of an ideological orientation that is carried out in the form of public lectures and reading books. This activity is carried out for students' understanding of the soul, history, values, and philosophy of Gontor. Then the noble values taught during the study period in pesantren can be embedded.

\section{IKPM Gontor}

Gontor Alumni spread throughout Indonesia, and the world formed a family organization called the Pondok Modern Family Association (IKPM) under the auspices of Pondok Modern Darussalam Gontor. Several Overseas IKPM officially established were IKPM Malaysia, IKPM Brunei Darussalam, IKPM Europe, IKPM Cairo, IKPM Saudi Arabia, IKPM Madinah, IKPM Sudan, and IKPM Turkey. The requirement to establish IKPM is to have a minimum of 5 members [35]. This organization stands on the initiative of alumni who have been scattered. European IKPM, which has a base in the Western European region, established in 2016. Because of the territory that includes cross-country, Gontor alumni communicate using social media and gather in Germany and the Netherlands. Indonesian Embassy gave support to this establishment [36].

As a transnational organization, IKPM was born based on equality of identity and values. The Gontor Islamic Boarding School 'only' educational institutions that do not have a basis of ideological movements such as community and regional organizations. Gontor Alumni have the same experience and education, both women and men. Emotional feeling possessed is almost similar, especially with the value since santri. The drastic differences in educational backgrounds between Gontor pesantren and traditional pesantren or Gontor Pesantren and 
public school alumni allow alumni to categorize themselves. The unity of the meaning system that finally forms a sense of shared identity [37]

\section{IKPM Gontor in the Middle East}

Gontor Alumni have a fraternal organization under the auspices of the Pondok Modern Family Association (IKPM) established in 1949. After the signing of the waqf of Gontor Islamic Boarding School to Muslims in 1951, IKPM became one of the benchmarks of Gontor's progress and setback in fostering alumni [38]. Now structurally, IKPM is under the leadership of Pesantren and is not a stand-alone Association [39]. So that the Gontor Islamic Boarding School still fosters and educates its alumni through meetings and activities that are driven by IKPM. No exception to the Middle East region where the majority of its members are students.

Although different from other diaspora groups based on nationality, regionalism, funding, or mass organizations, such as PCI-NU and PPMI, IKPM as an alma mater community also has a secure attachment for the diaspora to form groups [40]. The purposes of the establishment of the IKPM Cairo are maintaining Pesantren Gontor's right name, maintaining relations with AlAzhar University as an extended arm of the Gontor Islamic Boarding School because of the large number of Indonesian students, while IKPM in other countries with a smaller number strives to have IKPM as a place for Gontor alumni hospitality [41].

The recruitment of IKPM members is done through several channels, namely from the IKPM, who are looking for new student data through PPI or the student who is contacting the IKPM management via official social media. The typology of the majority of IKPM members in the Middle East are students studying Islamic studies. Some diaspora work as entrepreneurs and staff of embassy, diplomats or ambassadors. IKPM activities are different from other countries because of the number of members and the environment - the presence of Indonesian students at Al-Azhar University since the 1850s [42]. The first person to study at this campus was known to be Abdul Manan Dipomenggolo, founder of the Tremas pesantren in Pacitan, East Java. The Cairo branch of the Gontor IKPM established in 1979. Currently, around 6000 Indonesian students are attending Al-Azhar and Gontor alumni totaling 775 people per 2019 [43].

The conditions for establishing IKPM are a minimum of 5 members. If in one country the number is met, then the official SK IK establishment of the branch can be lowered. However, the most common obstacle is the difference between the campus and the city between students or the diaspora. So that communication and mobilization access is hampered. Turkey's IKPM in 2012 was established with ten initial members. The active members of the Turkish PPI and direct communication with the Central IKPM management facilitated the formation of the Turkish IKPM. According to Deden, the typology of graduate students is also a factor of IKPM activity [44].

IKPM is a suitable place for Gontor alumni activities. In some countries that do not yet have an official IKPM, the activities carried out are only about gathering. However, the IKPM alumni have more impact on carrying out family activities that are more organized and take part in both the local country or the cottage. Sudan IKPM, for example, they have a select committee every year mentoring prospective students and helping with documents such as the visa and student application for Gontor alumni [45]. Bureaucracy and administration in Sudan are quite tricky and takes a long process. 
Gontor Alumni who have this association eventually become one of the Islamic references in several countries. Because of knowing explicit scientific knowledge without any political tendencies or tendencies in specific community organizations, religious activities at the Indonesian Embassy in Ankara prefer IKPM members as the performers. The friction of ideology spread in the Middle East several times due to differences in Islamic style in Indonesia. This familial nature is a bridge between alumni to remind one another so as not to be exposed to radical Islam.

\section{Conclusion}

IKPM Gontor, as a transnational organization, has a strong network between alumni and pesantren. Some pesantren values are still being conveyed, and activities characteristic of students are carried out. Socially, IKPM has not been able to play a role in the international realm. Nevertheless, for the diaspora, they already have a vital position in activities and religion. Gontor Islamic Boarding School only facilitates activities carried out by alumni with supervision. No particular purpose is given except to preserve the value and right name of Gontor. Meanwhile, the existence of an official forum like IKPM, it can control alumni in the name of kinship.

The Middle Eastern style of Islam that is slightly different from Islam in Indonesia, requires a filter. Although the goal of Gontor students was in the Middle East because of further studies, the filter that can be carried out by IKPM carries the values of pesantren that have been studied so as not to be exposed to radicalism. Differences in CSO backgrounds are not an essential issue in the IKPM body because of the reasonable basis with the slogan standing above and for all groups.

\section{References}

[1] Geertz, C.: Religion of Java. London: The University of Chicago Press. (1976)

[2] Bruinessen, M. v.: Developments in Indonesian Islam: Explaining the "Conservative Turn". Institute of Southeast Asian Studies, Singapore (2013)

[3] Dhofier, Z.: Tradisi Pesantren: Studi Pandangan Hidup Kyai dan Visinya Mengenai Masa Depan Indonesia (Edisi Revisi). LP3ES, Jakarta (2011)

[4] Zulkarnain, F.: The Thought of KH Imam Zarakasyi on Multicultural Education at Modern Islamic Boarding School Gontor Ponorogo. Jurnal Pendidikan Islam Vol. 2, No. 1, 68-87. (2015)

[5] Suhadi, I.: Mendidik Ikhlas, Beramal, dan Berjuang. In K.H. Imam Zarkasyi di Mata Umat pp. 653656. Gontor Press, Ponorogo (1996)

[6] Vertovec, S.: Transnationalism. Routledge, New York (2009)

[7] Breneau, M.: Diasporas, Transnational Spaces and Communities. In R. Baubock, Diaspora and Transnationalism: Concepts, Theories and Method. pp. 37-38. Amsterdam University Press, Amsterdam (2010)

[8] Faist, T.: Diaspora and Transnationalism: What Kind of Dance Partners? In R. B. (Eds), Diaspora and Transnationalism: Concepts, Theories and Methods. pp. 9-34. Amsterdam University Press, Amsterdam (2010)

[9] Abrams, M. A.: Social Identification. Routledge, New York (2006)

[10] Suryanto.: Pencarian Identitas Sosial (Fluidity of Social Identity) Sebagai Indikator Loyalitas Terhadap Organisasi: Suatu Kajian Kritis Dasar Komitmen Terhadap Organisasi. Temu Ilmiah dan Konferensi II Asosiasi Psikologi Industri dan Organisasi. Bandung (2005) 
[11] Azra, A.: Jaringan Ulama Timur Tengah dan Kepulauan Nusantara Abad XVII \& XVIII: Akar Pembaruan Islam Indonesia (Edisi Perenial). Kencana, Jakarta (2010)

[12] Yusoff, K.: Transistion in Turkey: An Overview of Bediuzzaman Said Nursi, His Life, and Works for Medresetu Zehra. International Journal of West Asian Studies Vol. 5 No. 2, pp. 67-77. (2013)

[13] Swahananda, S.: Monasteries in South India. Vedanta Society of Southern California, California (1990)

[14] Dhofier, Z. (2011)

[15] Fauzi, M. L.: Traditional Islam in Javanese Society: The Roles of Kyai and Pesantren in Preserving Islamic Tradition and Negotiating Modernity. Journal of Indonesian Islam Vol. 6 No. 1, pp. 125-144. (2012)

[16] Ziemek, M.: Pesantren Dalam Perubahan Sosial. PT. Temprint, Jakarta (1986)

[17] Lukens-Bull, R.: Madrasa by Any Other Name: Pondok, Pesantren, and Islamic Schools in Indonesia and Larger Southeast Asia Region. Journal of Indonesian Islam Vol. 4 No. 1, 1-21. (2010)

[18] Sanusi, M. H.: Trimurti: Menulusuri Jejak, Sintesa dan Geneologi Berdirinya Pondok Modern Darussalam Gontor. Etifaq, Bantul (2016)

[19] Dhofier, Z. (2011). Ibid

[20] Bruinessen, M. v.: Kitab Kuning: Books in Arabic Script Used in Pesantren Mileu. Bijdragen tot de Taal-, Land-, en Volenkunde 146, pp. 226-229. (1990)

[21] Lukens-Bull, R.: A Peaceful Jihad: Negotiating Identity and Modernity in Muslim Java. Palgrave Macmillan, New York (2005)

[22] Bruinessen, M. v.: Traditionalist and Islamist Pesantrens in Contemporary Indonesia. In F. A. Noor, Y. Sikand, \& M. v. Bruinessen, The Madrasa in Asia: Political Activism and Transnational Linkage. pp. 217-246. Amsterdam University Press, Amsterdam (2008)

[23] Lukens-Bull, R. (2005). A Peaceful Jihad

[24] Zarkasyi, A. S.: Manajemen Pesantren: Pengalaman Pondok Modern Gontor. Trimurti Press, Ponorogo (2005)

[25] Zarkasyi, A. S. (2005)

[26] Zarkasyi, A. S.(2005)

[27] Sanusi, M. H. (2016)

[28] Sanusi, M. H. (2016)

[29] Wiryosukarto, A. H.: Biografi K.H. Imam Zarkasyi: Dari Gontor Merintis Pondok Modern. Gontor Press, Ponorogo (1996)

[30] Sosroatmodjo, A.: Meningkatkan Mutu Madrasah. In K.H. Imam Zarkasyi di Mata Umat pp. 636638. Gontor Press, Ponorogo (1996)

[31] Bruinessen, M. v.: Rakyat Kecil, Islam, dan Politik. Gading Publishing, Yogyakarta (2013)

[32] Madjid, N.: K.H. Imam Zarkasyi: Peran dan Ketokohannya. In K.H. Imam Zarkasyi di Mata Umat. pp. 965-972. Gontor Press, Ponorogo (1996)

[33] Steenbrink, K. A.: Almarhum yang Mukarram: Par Zarkasyi Seorang Pragmatikus dalam Pembinaan Pesantren. In K.H Imam Zarkasyi di Mata Umat. Gontor Press, Ponorogo (1996)

[34] Zarkasyi, N. Z.: Memoar Gontor. pp. 19. Trimurti, Ponorogo (2018)

[35] Prasetya, I. B. Chief of IKPM Headquarter. (D. A. Purwaningtyas, Interviewer) (2019, August 21) [36] Maulana, A. M. Co-Founder of IKPM Branch Europe. (D. A. Purwaningtyas, Interviewer) (2019, August 20)

[37] Hariadi.: Evolusi Pesantren: Studi Kepemimpinan Kiai Berbasis Orientasi ESQ. LKiS, Yogyakarta (2015)

[38] Sejarah PP-IKPM Gontor. Retrieved from IKPM Gontor: http://ppikpm.gontor.ac.id/sejarah/.

[39] Struktur. Retrieved from Pondok Modern Darussalam Gontor: https://www.gontor.ac.id/struktur

[40] Bruneau, M.: Diasporas, Transnational Spaces and Communities. In R. B. (Eds), Diaspora and Transnationalism: Concept, Theories and Methods. pp. 35-50. Amsterdam University Press, Amsterdam (2010)

[41] Haris, N. Chief of IKPM Kairo. (D. A. Purwaningtyas, Interviewer) (2019, Februari 4)

[42] Misrawi, Z.: Al-Azhar: Menara Ilmu, Reformasi dan Kiblat Keulamaan. Penerbit Buku Kompas, Jakarta (2010) 
[43] Said, M. "Safiru Indunisiya bi al-Qahirah: Ziyadatu 'Adada al-Thullabi al-Darisin bi Al-Azhar ila 6 Alafin Thalibin". Retrieved from http://gate.ahram.org.eg/News/1980932.aspx.

[44] Drajat, D. M. Founder of IKPM Turki. (D. A. Purwaningtyas, Interviewer) (2019, September 23)

[45] Nuruddin. Member of IKPM Sudan. (D. A. Purwaningtyas, Interviewer) (2019, September 19) 